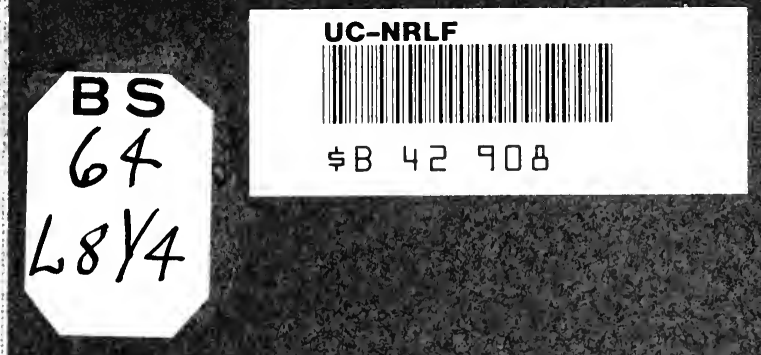




\section{IXCHANGE}

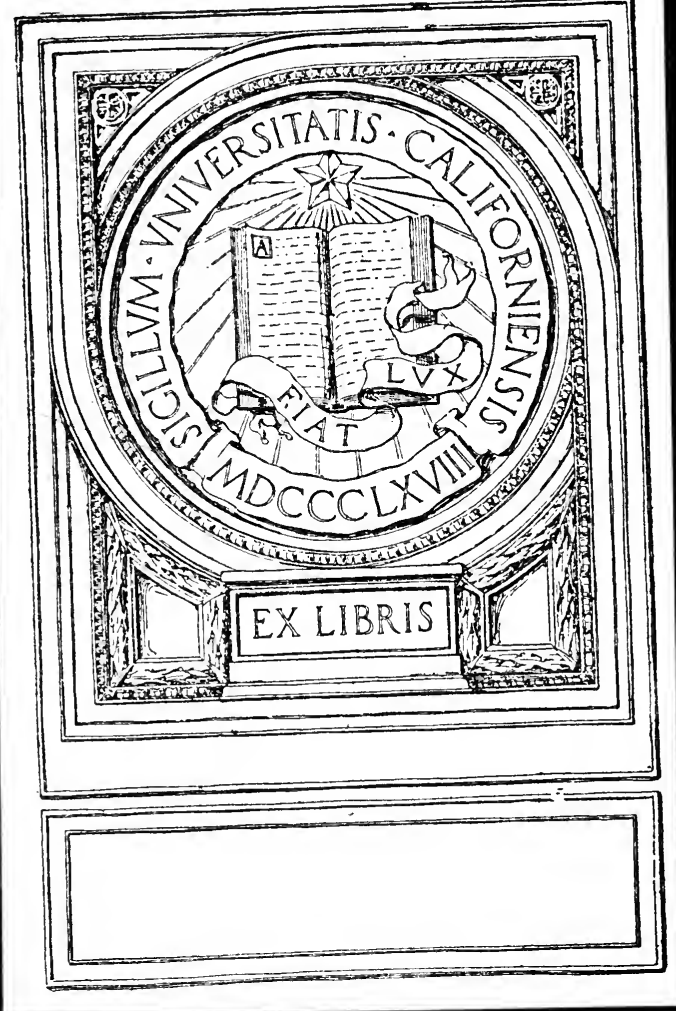


UNIVERSITY OF PENNSYLVANIA

\section{THE LUCIANIC VERSION OF THE OLD TESTAMENT AS ILLUSTRA- TED FROM JEREMIAH 1-3}

BY

BOYDEN KEITH YERKES

\section{A THESIS}

PRESENTED TO THE FACULTY OF THE GRADUATE SCHOOL IN PARTIAL FULFILLMENT OF THE REQUIREMENTS FOR THE DEGREE OF DOCTOR OF PHILOSOPHY 



\title{
THE LUCIANIC VERSION OF THE OLD TESTAMENT AS ILLUSTRA- TED FROM JEREMIAH 1-3
}

\author{
BY \\ BOYDEN KEITH YERKES \\ "Y
}

\section{A THESIS}

PRESENTED TO THE FACULTY OF THE GRADUATE SCHOOL IN PARTIAL FULFILLMENT OF THE REQUIREMENTS FOR

THE DEGREE OF DOCTOR OF PHILOSOPHY 


$$
3)^{6} e^{x} y^{x}
$$

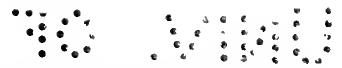

" 
Reprinted from Journal of Biblical Literature, Vol. XXXVII, 1918.

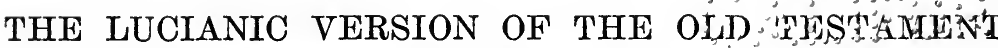
AS ILLUSTRATED FROM JEREMIAH 1-3*

\author{
ROYden Keith YeRkeS \\ University of P.ennstluania
}

The quest of the Lucianic text of the Greek Old Testament, which was undertaken with such vigor a generation ago under the able leadership of Field and Lagarde, has become little more than an avocation among scholars since the death of those two pioneers. The importance of this work consists in the fact that the Lucianic version was one of the three great Christian recensions of the Greek Old Testament in the third and fourth centuries.

* Chronological Bibliography. 1798 Holmes, Praefatio in Pentateuchum; 1864 Vercellone, Variae Lectiones; 1875 Field, Origenis Hexaplorum quae supersunt, Prolegomena, ch. IX; 1876 Nestle, Review of Field's "Hexapla," ThLZ, I, 7, pp. 179-183; 1882 Hort, Introduction to the N.T. in Greek, p. 86; 1882 Hollenberg, Review of Lagarde's "Ankündigung," ThLZ, VII, 7, pp. 145-147; 1883 Lagarde, Librorum Veteris Testamenti Canonicorum Pars Prior; 1884 Lagarde, Mittheilungen, I, pp. 122-124; 175-176; 1884 Smith, Review of Lagarde's "Septuagint," O. T. Student, Sep., pp. 37-39; 1886 Cornill, Das Buch des Propheten Ezechiel, Prolegomena, pp. 65-66; 1886 Nestle, Septuaginta Studien; 1887 Reckendorf, " Über den Werth der altäthiopischen Pentateuchübersetzung für die Reconstruction der Septuaginta," ZATW, VII, pp. 61-90; 1890 Driver, Notes on the Hebrew Text of Samuel; 1892 Stockmayer, "Hat Lucian zu seiner Septuagintarevision die Peschito benützt?', $Z A T W$, XII, pp. 218223; 1893 Harnack, Die altchristliche Literatur, pp. 526-531; 1894 Harnack, Dogmengeschichte, Eng. Tr., IV, pp. 3-7; $1895 \mathrm{Mez}$, Die Bibel des Josephus; 1896 Nestle, Septuaginta Studien II; 1896 Burkitt, The Old Latin and the Itala, p. 9; 1898 Wendland, "Zu Philos Schrift De Posteritate Caini,"' Philologus, LVII, 249-287; 1899 Nestle, "Zur Reconstruction der Septuaginta,'’ Philologus, LVIII, 121-131; 1899 Smith, Samuel, pp. 402-407; 1900 Swete, Introduction to the O. T. in Greek, pp. 80-85; 1901 \&, "Lucian's Recension of the Septuagint," Ch. Quar. Rev., pp. 379-398; 1902 Harnack, Lucian der Märtyrer, Hauck's Real-Enc.; 1902 Liebmann, Der Text zu Jesaia 24-27, ZATW, pp. 285-305; 1910 Harnack, Lucian the Martyr, New Schaff-Herzog, VII, 53-54; 1910 Procksch, Septuaginta Studien, pp. 76-87; 1913 Srawley, Antiochene Theology, Hastings $E R E$, I, pp. 584-585. 
Jerome, writing less than a hundred years after the death of Iucian, remaked, Alexandria et Aegyptus in LXX suis Hesychium laudat austorem. Constantinopolis usque Antiochiam Turciani Martyiris exemplaria probat. Mediae inter has provinciae Palaestinos codices legunt quos ab Origene elaboratos Eusebius et Pamphylius vulgaverunt: totius orbis hac inter se trifaria varietate compugnat. ${ }^{1}$ About the same time he wrote, In quo illud breviter admoneo, ut sciatis aliam esse editionem, quam Origenes et Caesariensis Eusebius omnesque Graeciae tractatores кoùn, id est communem, appellant, atque vulgatam, et a plerisque

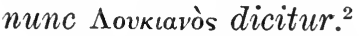

With the early life of Lucian we are not concerned; at best the facts are so meager and so obscured that little can be said with certainty. He first appears at Antioch as a vir disertissimus Antiochenae Ecclesiae presbyter. ${ }^{3}$ He may have been the leader of the theological school centered there; his was at least a dominating influence, and it was under him that the Antiochene school of theology first came into the clear light as actuated by distinctive principles.

Theologically this school was marked by the early use of Aristotelian philosophy. In biblical work it was characterized by principles of literal interpretation, as contrasted with the allegorical method of the school of Origen, while it made free use of textual criticism as far as possible. That Lucian was influenced by these suspect principles may be inferred from the fact that he lived for nearly thirty years apart from the Church. ${ }^{4}$ $\mathrm{He}$ was finally restored to communion, and suffered martyrdom under Maximian in 311 or 312 at Nicomedia. ${ }^{5}$

While at Antioch Lucian was famed for his biblical learning. ${ }^{6}$ In company with the Hebrew scholar Dorotheus he undertook the preparation of an edition of the Old Testament in Greek.

${ }^{1}$ Jerome, Contra Rufinum 2:26; Praefatio ad Paraleipomena.

${ }^{2}$ Jerome, Epistola 106 Ad Sunniam et Fretelam.

${ }^{3}$ Jerome, De viris illustribus, $7 \%$.

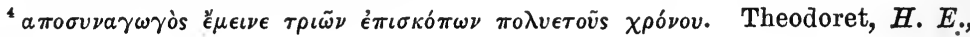
1: 3 .

${ }^{5}$ Eusebius, H. E., 8: 13; Sozomen, H. E., 3:5; Georg. Ced., 517; Theophanus, Chronographica, 9; Nicetas, Praef. Cyr. Alex. In Psalmos; Jerome, De viris illus., 7r; ; Pseudo-Athanasius, Synopsis Sacrae Scripturae.

${ }^{8}$ Eusebius, H. E., $9: 6$. 
Pseudo-Athanasius, in the Synopsis Sacrae Scripturae, describes

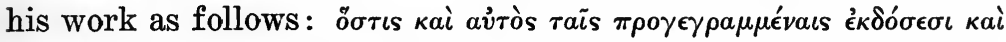

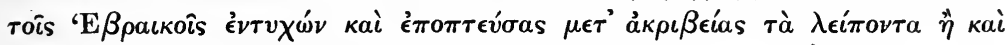

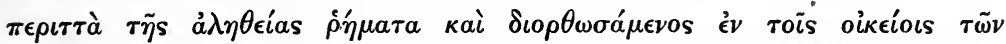

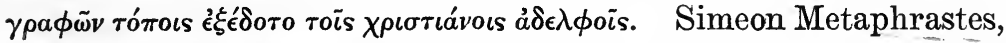
writing about 965 , suggests that the Greek texts were quite corrupt at the time of Lucian. These corruptions had arisen partly by the accidents of translation and retranslation, and partly from deliberate efforts to pervert the meaning of the text. Lucian is said to have retranslated the whole of the Old Testament into Greek from the Hebrew, of which he is described as having had a very accurate knowledge. His work gained great prevalence in the region of which Antioch was the center, and was of such importance that Pseudo-Athanasius speaks of the translation as $\dot{\eta} \dot{\epsilon} \beta \delta \delta^{\prime} \mu \eta$, while Jerome ranks it with that of Origen.

Since Lucian's version, and all copies which were possibly made from it, have long since been lost, it becomes necessary, before any estimate of his work can be given, to attempt to make a restoration of his recension by a study of existing manuscripts. It may then be possible to judge whether Jerome's description of his work was not too meager and whether Simeon Metaphrastes did not err on the other side by attributing too much to the work of the Antiochene scholar. It may also be possible to form some idea of the Greek translations with which he was familiar, and of the Hebrew text from which he made his corrections or his translation, as the case may be.

It has usually been assumed that all the manuscripts of the Greek Old Testament can be traced, or could be traced if the means were accessible, back to an original "Septuagint," or translation of the Old Testament into Greek; or that early translators, as, e. g., Aquila, Theodotion, Symmachus, Origen, Hesychius and Lucian, had some such uniform copy upon which to base their efforts. From this assumption much Septuagint work has proceeded.

Now it has long been noticed that no two manuscripts of the Greek Old Testament agree with each other, although some show greater kinship than others. A study of a single manuscript, however, e. g., the B text, reveals some interesting facts. There 
are certain parts of the Old Testament which, in the Masoretic text, are duplicates of each other. If any one Greek manuscript were a consistent and uniform translation, or copy of such translation, it would be expected that these duplicates would be translated somewhat alike. As a matter of fact, an examination shows that even in these parts there are such variations as to lead to the conclusion that two entirely different hands were at work in the two places.

In the Appendix to this paper will be found a table of six columns of which the second and the fifth will occupy our attention at present. In these columns will be found readings from the $B$ texts of 2 Kings $19: 1-6$ and Isaiah $37: 1-6$ in which the Hebrew texts are repeated practically verbatim. In these six verses there are thirty variants. Six are differences in grammar; three are differences in number; one is in the order of words ; eleven are differences of vocabulary; there are six omissions in Isaiah as against Kings and four in Kings as against Isaiah.

This table is followed by a similar one comparing 2 Kings 24:18-25:8 with Jeremiah 52:1-12 which are alike in the Hebrew. The B texts of these two sections reveal the following differences: twelve in grammar, ten in vocabulary, two in the spelling of proper names, one in the order of words, one in number, four in the forms of verbs, two in the reading of the original Hebrew, four omissions in Kings against Jeremiah, while Jeremiah omits two whole verses and two minor words against Kings. A study of these readings and variations leads to two conclusions :

1. The Hebrew texts, while they are alike at present, were certainly not alike at the beginning.

2. The Greek translations were made not only from different Hebrew texts and by different hands, but probably by different schools and at different times.

The probability is that there was not in the early centuries any such thing as "The Septuagint," but that the Greek version of the Old Testament came into life very like the English Bible. It was probably preceded by various translations of single books, or groups of books, contributed by different hands who worked over the space of several centuries. The first part to be translated was undoubtedly the Torah, which may have been rendered 
in an official, or semi-official manner, as the letter of Aristeas suggests. This was followed by translations of other parts as need arose or as men had the inclination. ${ }^{7}$

Even in the first century of our era there was no uniform version of the Greek Old Testament, as is borne out by a comparison of the New Testament with any known version or manuscript of the old Testament. Endeavors have been made ${ }^{8}$ to ascertain what version or versions the New Testament writers used, but with little more than tentative hypotheses as results, and with no unanimity of opinion.

Philo, to be sure, refers to an annual festival ${ }^{9}$ on the island of Pharus commemorative of the completion of the translation of the Old Testament into Greek, but this would connote no more than the fact that all the books had been translated.

There is no evidence of an attempt to produce a uniform rendering of the Old Testament into Greek until the second century of our era and after that time there were two different influences at work. The first was the Jewish-Ebionitic influence which produced the versions of Aquila, Theodotion and Symmachus; the second was the Christian influence which animated Origen, Hesychius and Lucian of Antioch.

In tracing the lineage of the Greek texts of the Old Testament it must be remembered that there was probably no uniform Hebrew text from which the earliest translations were made. There may have been an official Hebrew text of the Torah at the time this part was translated into Greek. This was, in all probability, before the composition of many parts of the Nebiim and certainly before the completion of the Kethubim. As these later writings were produced, translations of them were made into Greek, possibly long before they were accorded the dignity of canonicity, and certainly long before the Hebrew text had become fixed. Swete ${ }^{10}$ calls attention to the fact that "no official text held undisputed possession in the first century or was recognized by the writers of the New Testament." And inasmuch as the content of the Hebrew Canon was not fixed until the end of the

\footnotetext{
'Nestle, in Philologus, vol. LVIII, came to the same conclusion, but based his arguments upon entirely different grounds.

${ }^{8}$ Swete, Introduction to the Old Testament in Greek, Part III, ch. ii.

${ }^{-}$Quotation in Swete, op. cit., p. 13.

${ }^{10}$ op. cit., p. 439.
} 
first century of our era, and the Hebrew text until much later, it would be surprising if there were any such thing as a uniform Greek translation. In fact, there is no evidence of any attempt at a uniform rendering of the whole Old Testament, or rather a uniform collection of the Graeco-Jewish literature until the version of Aquila. By this time both the Hebrew texts and the Greek translations of individual books had been copied so often that there was already a considerable disparity between them.

The translations of the third century Christian scholars are analogous, in a general way, to the King James, the Douay and the Revised versions of the Bible in English. ${ }^{11}$ Attempts were made to render the entire Bible into the vernacular. These attempts were based upon whatever former translations were accessible to the scholars as well as upon the studies of these scholars in the original texts. Their results were never universally recognized and their use was locally or theologically confined to those who were in sympathy with the translators. Any attempt to restore an original Septuagint, therefore, becomes impossible. At Alexandria, at Antioch and at other metropolitan cities there were probably collections of rolls of translations made by entirely different hands and at different times.

Our present problem is the construction, with the aid of known manuscripts, of a hypothetical text which we may assume to resemble somewhat the translation of Lucian, and, from this hypothetical text, to estimate the character of the work of Lucian.

The efforts to recover the text of Lucian are largely the work of scholars of the last generation. Robert Holmes called attention $^{12}$ in 1798 to the similarity existing between the Complutensian Polyglot and codices 19.108.118. Vercellone ${ }^{13}$ wrote in

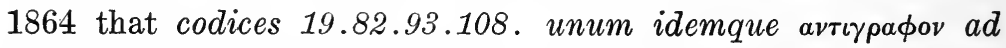
singularem quandam recensionem spectans representare. Neither of these writers, however, suggested a connection between the codices mentioned and the recension of Lucian.

The first stride toward an attempted recovery of the recension was made by Frederick Field in 1875 in his Origenis Hexaplorum

${ }^{11}$ Nestle, op. cit., makes the same comparison with the various German translations of the Bible.

${ }^{12}$ Praefatio in Pentateuchum.

${ }^{13}$ Variae Lectiones 2: 436. 
quae supersunt. A note prefixed to the Arabic translation of the Syro-Hexaplar read: Lucian compared with greatest care these Hebrew copies, and if he found anything lacking or superfluous he restored it to its place, prefixing to the part amended the initial letter $L$. This method of marking, absent from most manuscripts, was found in the Syro-Hexaplar. A single examplewill illustrate Field's method.

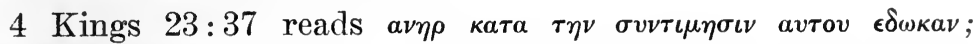

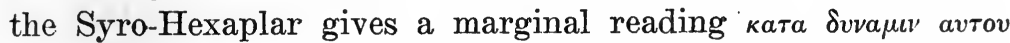
and indicates that it is Lucianic. A reference to Holmes-Parsons in loco shows that this reading is supported by codices 19.18. 93.108 and the Complutensian. Careful study led Field to the conclusion $^{14}$ certissime concludi arctam propinquitatem, nedum identitatem, inter Luciani editionem et codices 19.82.93.108.

Meanwhile Paul de Lagarde had been working upon an entirely independent line and his conclusions were published in his Librorum Veteris Testamenti Canonicorum Pars Prior in 1883. Commencing with the suggestions of Holmes and Vercellone; he established the relationship between codices 19.82.93.108.118 and the Complutensian Polyglot. He collected Old Testament quotations of Chrysostom and found that his readings were supported by members of this group of codices. He then made use of the statements of Jerome concerning the three families of Greek recensions and assumed that, of these three families, the Lucianic would be the one most likely to be used by Chrysostom and Theodoret. He also found that, as far as he was able to compare, the Gothic variants were supported by the same group of codices. This led him to construct the text published by him as the Lucianic recension.

An examination of Lagarde's work shows that there is no exact agreement between the manuscripts upon which he based his text. The following examples from Ex. 1:1-10 will suffice to illustrate:

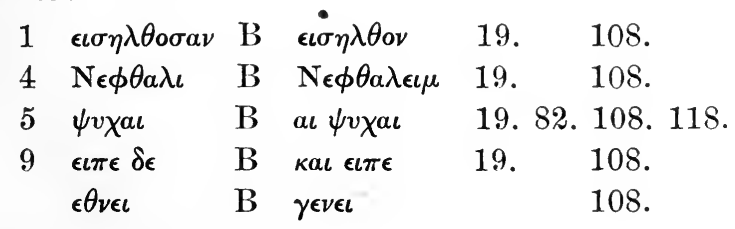

${ }^{14}$ p. Ixxxvii. 


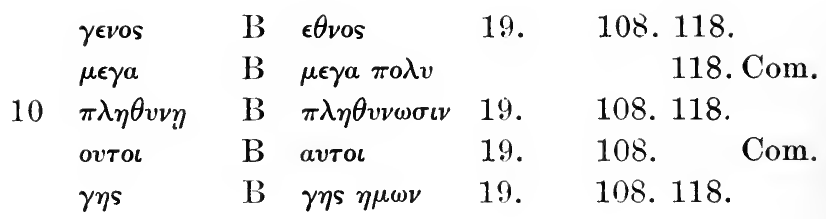

Thus it will be seen that there is no single manuscript which gives all the readings adopted by Lagarde. Codex 82 is closely related to $\mathrm{B}$ in the Pentateuch, while 93 does not contain the Pentateuch. Of the others it will be noted that, out of ten readings adopted by Lagarde, two are not given by 19, one is not given by 108, while five are not given by 118 and the Complutensian gives only two. At best, then, Lagarde's text is but a tentatively hypothetical restoration of what may have been the text approximating that of Lucian.

An examination of his comparisons with the readings of Chrysostom shows no closer agreement. Codices 19.93.108.118 in the main support the readings of Chrysostom, but every one of them is absent occasionally, while 82 very seldom agrees. The result, then, is but tentative and hypothetical, although as a tentative hypothesis it has not been displaced.

The important fact is that Lagarde and Field, working independently of each other and on entirely different lines, reached practically the same conclusions, excepting the fact that Field makes no mention of codex 118 which Lagarde found so important.

It had been the intention of Lagarde to publish a second part containing the remaining books of the Old Testament, but his death in 1891 left his work unfinished and no scholar has since undertaken the task. Field, however, laid the foundation for the study of the Lucianic version of the prophets. Upon the basis of the similarity between readings of Theodoret and the group of codices 22.36.48.51.62.90.147.231.233, he classified these codices in the same family. Gomparison of marginal notes on codex 86 indicated by the symbol $\lambda$ showed kinship with this group, to which he therefore assigned Lucianic influence.

Cornill, in the Prolegomena to his Ezechiel, published in 1886, discussed the subject at length and came to certain definite conclusions, as far as Ezekiel was concerned. He agreed with Field in attributing the group 22.36.48.51.231 to Lucianic influence. 
To this group he added the fragment called $\mathrm{Z}^{\mathrm{c}}$ which contains but a small portion of Ezekiel. He rejected 62.90.147.233 because sie theilen mit Lucian eine Anzahl von hexaplarischen Zusätsen, geben aber nicht die Recension Lucians.

The most recent investigation of the subject has been pursued by Dr. Otto Procksch of Greifswald ${ }^{15}$ who divides the manuscripts into three general groups which he styles the Hexaplaric, the Prehexaplaric and the Lucianic. In Jeremiah he assigns 33.87.91.228 (41.49.90) to the first group. To the second group he assigns 26.86.106.198.233.239.(41.49.90). To the Lucianic group he assigns 22.36.48.51.96.144.229.231.

The grouping by the several scholars of the manuscripts which are said by them to show more or less of Lucianic influence may be summarized as follows:

\begin{tabular}{|c|c|c|c|c|}
\hline $\begin{array}{l}\text { Field } \\
\text { Cornill }\end{array}$ & $\begin{array}{l}22.36 .48 .51 .62 .90 .93 \\
22.36 .48 .51 .\end{array}$ & 144. 147 . & $\begin{array}{l}231 \\
231\end{array}$ & 233.308 \\
\hline Klostermann & 48.62 & 147. & 231 & \\
\hline Nestle & 22.36 .48 .51 .62 .90 .93$. & 144. 147 . & & 233.308 \\
\hline Liebmann & 22.36 .48 .51 .62 .90 .93$. & 144. 147 . & & 233 \\
\hline Procksch & 22.36 .48 .51 . & 96.144 . & 229.231 & \\
\hline Burkitt & 22.36 .48 .51 . & 96. & 229.231 & \\
\hline
\end{tabular}

In determining those texts of the prophets which show traces of Lucianic influence and which would therefore be of assistance in restoring the Lucianic text, the work of Lagarde in the Octateuch is of real service. Lagarde's text is a hypothetical restoration of the Lucianic recension and the critical apparatus is given only in the book of Esther. For the purposes of the present study, however, it will be assumed that it approximates the text of Lucian.

Two passages in $4 \mathrm{Kings,}$ to which reference has already been made, are reproduced practically verbatim in the Masoretic texts of the prophets. 4 Kings $19: 1-6=$ Isaiah $37: 1-6$ and 4 Kings $24: 18-25: 8=$ Jeremiah $52: 1-12$.

In the first pair of passages there are twenty-eight instances in which the $B$ text of Kings differs from that of Isaiah while the Masoretic texts are alike. In seventeen of these twenty-eight instances, the text of Lagarde agrees with the B text of Kings. Of the eleven variants between $B$ and Lagarde's text, four of the readings of Lagarde agree with the

${ }^{15}$ Studien zur Geschichte der Septuaginta, 1910. 
B text of Isaiah. Three of Lagarde's readings are sui generis, while the remaining four are confirmed in Isaiah by four or more members of the group 22.36.48.51.62.90.144.147.228.233.308.

In Kings there are fourteen readings of Lagarde which vary from B. Four of these agree with all the texts of Isaiah; six are sui generis readings of Lagarde, while four are confirmed in Isaiah by members of the group Q.22.36.48.51.62.90.91. 144.147.198.228.308. Comp.

In Isaiah there are seventeen readings in which two or more members of the group Q-Comp. give a reading different from that of B. Six of these agree with all the texts of Kings; two agree with the B text of Kings as against Lagarde; five are sui generis readings; four are confirmed in Kings by the text of Lagarde.

From this comparison it would seem that some of the manuscripts forming the group Q-Comp. give evidence of the same influence which is seen in the manuscripts of the Octateuch which Lagarde called Lucianic.

In the second pair of passages there are forty-seven instances in which the B text of Kings differs from that of Jeremiah. In twenty-four of these the text of Lagarde agrees with the B text of Kings. In the remaining twenty-three instances there are nine cases in which Lagarde's reading agrees with all the texts of Jeremiah, one in which it agrees with the B text alone, and six in which it is supported by members of the group Q.22.26.36.48.51.62.88.90.91.96.106.144.198.228.231.233. 239. Comp.

In the same pair of passages there are thirty-three instances in which Lagarde's reading differs from the B text of Kings. Of these there are five instances in which the B text is supported by all the texts of Jeremiah, ten in which Lagarde's reading is supported by all the texts of Jeremiah, eleven in which Lagarde gives a sui generis reading and seven in which Lagarde is supported by members of the group Q-C.

At the same time there are twenty-four places in which members of the group Q-Com. give a different reading from that of the B text of Jeremiah. Four of these are in agreement with all the texts of Kings, eleven are sui generis readings and seven are supported by Lagarde. These seven readings are given by the following texts : 
22. 36.48 .51 .62 .

96.

198. 231 .

22. 36.48 .51 .62 .88 .90 .91 .96 . 144.198.228.231.233.239.Q.Com.A.

22. 36.48 .

96.

$52: 1$

26.36. 51.62 .88 .90 .96$.

144.198 .228

233.239 .

Com.A. $52: 4$

22. 36.48 .51 .62 .

96.

198. 231 .

$52: 4$

22.26 .36 .48 .51 .62 . 90.91.96.106.144.198.228. 233 . 91.96 .106 . 198.228.231.

Q.Com.A. $52: 12$

36.48 .51 .62 .

The classification of the variant readings gives the first step toward the grouping of the manuscripts. For this I have examined the text of Jeremiah 1-3, noting the variant readings of Q. A. Comp. 22.26.36.48.51.62.88.90.91.96.106.144.198. 228.229.231.233.239. and Theodoret. This study is based upon the collation of Parsons which scholars have all recognized as very faulty. I have compared his collation of $A$ and $Q$ with those of Swete and have found errors on every page. On the other hand, Swete's collation is far from faultless, so that final results can be obtained only by a study of the manuscripts themselves or of photographic plates. Parsons' collation of the readings of Theodoret I have compared carefully with Theodoret's Commentary upon Jeremiah, and the numerous errors of Parsons are only errors of omission.

There are, in the first three chapters of Jeremiah, four classes of variations which are here given in detail.

I. Agreement with the Masoretic text against other Greek texts.

II. General agreement of Greek texts against the Masoretic.

III. Difference from both the Masoretic and other Greek texts.

IV. Difference from other Greek texts in Greek.

I. Agreement with the Masoretic text.

1. Exact restoration of omissions.

a. Proper names.

1:11 Practically all the manuscripts collated by Parsons agree in this restoration.

b. Substantives and adjectives.

$1: 3 ; 2: 6 ; 2: 19 ; 3: 11 \quad 22.36 .48 .51 .96 .231$ are constant. 62 and 88 agree three times; 228 twice; 144.198.229.233.239 each once.

c. Pronouns.

$1: 16 ; 1: 17 ; 1: 18 ; 2: 21 ; 2: 28$ Nearly all the manuscripts occur. 22.36.48.51.62 alone are 
constant. 88 agrees in all but one and gives one in $2: 2$ where it is alone with $Q$.

d. Verbs.

$1: 4 ; 1: 19$ All the manuscripts appear. 22 . 36.48.51.62.88.96.231 are constant. In $3: 1$ is a restoration given only by Q.88.233.

e. Conjunctions.

$1: 3$ Restoration given by 22.26.36.48.51.62. 88.96.144.231.

f. Phrases, clauses and verses.

$1: 11 ; 1: 13 ; 1: 16 ; 2: 1 ; 2: 2 ; 2: 9 ; 2: 17 ; 3: 7$; $3: 8 ; 3: 10 . ; 3: 16 . . ; 3: 17$ The constants are 36.48.51.96.231. 22 and 62 each occur in every instance but one. 26.88.106.144. 228.229.233 agree occasionally. In 2:9 all. the manuscripts agree.

g. Particles.

$2: 15 ; 2: 16$ The constants are 36.48.96.231; 22.51.229 each once.

2. Partial restoration of omissions.

$1: 13 ; 2: 25$ 22.36.48.51.62.96.229.231 constant; unaccompanied by others.

3. Person and number.

$1: 4 ; 3: 6 ; 3: 11$ The last two are supported by most of the manuscripts. In the first only 51.88 . 90.91.106.198.233. Comp.

4. Correction of different reading or mistranslation by other texts.

$2: 6 ; 2: 11 ; 3: 2 ; 3: 25 \quad 22.51 .62 .96 .231$ constant. 36 and 48 each agree three times. 88.90.91.106. 144.228.239. A once each. 198.229.233 twice.

II. Agreement of Greek texts against the Masoretic.

The evidential value of these instances is chiefly negative. They illustrate the fact that none of the Greek texts is in complete agreement with the Masoretic. The instances are of interest chiefly as showing exceptions to the preceding class.

1. Retention of omissions.

$1: 18 ; 2: 7 ; 2: 30 ; 2: 34$. 
2. Retention of plus.

$1: 1,9,15,18 ; 2: 1,10,13,19,23,28,29,30,31$; $3: 6,7,8,12,17,18,21$.

3. Person and number.

$1: 2 ; 2: 1,11,12,18,20,25,30 ; 3: 13,18,19$.

4. Spelling of proper names.

$1: 2 ; 2: 18$.

5. Different reading or mistranslation.

$1: 7,14,15,17 ; 2: 2,6,13,19,24,26,29,31,33,34$; $3: 1,4,7,8,15,19,20,22$.

III. Difference from both Masoretic and other Greek texts.

1. Additions.

$1: 8,2: 2,6,8,9,12,14,28,31 ; 3: 2,20,22,23$, $24,26,27,29$ No constant. 22.36.51.96 are omitted each once. 48 and 231 omitted twice. 62 omitted three times. The others occur irregularly.

2. Omissions.

26.48.51.106 occur each once and alone. 22.48.51. 96.231 agree in $3: 2$. 48.51.62.96.106.144.231 agree in $3: 24$. 26.90.91.198.228 agree in $1: 8$. The other omissions are chiefly in 229 which is so fragmentary that the omissions signify nothing.

3. Miscellaneous.

$2: 3,14,31,34 ; 3: 22,24$ The constants are 22.48 . 51.231. 36.96.229 are omitted once each. 26 . 88.90.106.144.233 occur twice; the others once each.

IV. Differences from the other Greek texts in Greek.

1. Declension of proper names.

$1: 2,3 \ldots ; 3: 22$ But little agreement. 106 the only one absent. 88.144. Comp. agree in four instances. 48.96.231 occur four times each and agree in three.

2. Form of verb.

$1: 2,7,19 ; 2: 11 . ., 16,22,33 ; 3: 17,2496$ is the only constant. 36 and 231 appear in every instance but one. 51 occurs in all but two. 22 and 48 in all but three. 62.144.229 occur with a fair degree of regularity. 90 occurs twice, once with 88 and once with 91 . 
3. Second aorist ending.

$1: 6,11,13,17 ; 2: 5,6,8,17 ; 3: 2,7,19 . .22 .36$. 48.51 .96 constant. 231 appears in every instance but one. 62 agrees six times; 144 and 229 seven times each; 233 five times; 198 and 228 twice each. No others.

4. Different spelling.

$1: 18 ; 2: 3,8,13,21 ; 3: 5 \quad 36.48 .51 .62 .96 .144$. 229.231 agree five times. 22 and 106 occur four times. All others appear once or twice.

5. Use of particles.

$1: 7 . . ; 2: 6,10 ; 3: 8,12,2522.36 .48 .231$ agree in all instances; 26.62.144 in six ; 90.91.96 occur in four each; the others once or twice.

6. Vocabulary.

$1: 10 ; 2: 3 \ldots, 7,10,15 ; 3: 5,7,1322.51 .96$ agree in all ; 48.229 in all but one; 231 in all but one: 36 in all but two; 144 in all but three. The others appear irregularly.

7. Omissions.

$2: 27 \quad 22.36 .48 .96 .231 .233$ agree.

8. Order of words.

$1: 13,15,16,19 ; 2: 5,27,35 ; 3: 9,17 \quad 22.36 .48$. 62.96 agree in all ; 231 in all but one ; 51.88.144. 198.229.233 occur irregularly ; 26 twice; 90.106 . 228 each once.

9. Miscellaneous.

$1: 2 ; 2: 8,28,32 \ldots ; 3: 1296.231$ constant. 36 . 48 in all but one instance; 62 in all but one; 51 . 144.229 each in all but two; 22 three times; 106 . 233 each once; no others occur.

In the preceding analysis the agreement between 22.36.48. 51.96.231 is so general as to warrant the grouping of these manuscripts together as descendants of a common parent. This same grouping is also found, on page 170, of the texts with which Lagarde agrees. For the purposes of abbreviation I shall call this group L. ${ }^{16}$ Of the texts which constitute this group, the

${ }^{16}$ This study, and the conclusions drawn from it, were made before I had seen Procksch's Septuaginta Studien. It was at first somewhat sur- 
first four have been classified by all scholars since Field as unquestionably Lucianic, and the evidence from the present study simply confirms this opinion. Nestle and Liebmann were the only ones who did not include 231 in the group.

Codex 96 is described by Parsons as follows: $:^{17}$ Codex Hexaplaris, ex Bibliotheca cl. Moldenhaweri Hafniensis. Continet "4 Prophetas Majores; quantivis, ut videtur, pretii. Nevertheless it was collated only in Jeremiah and Lamentations, and accurate studies have not been made of it. In Jeremiah its readings practically coincide with those of 22.36.48.51.231; its absences are fewer than those of any of the others and it has fewer sui generis readings than any of the group. Burkitt ${ }^{18}$ called it Lucianic but gave no evidence for the classification. Procksch gives but a few readings from it in Jeremiah alone; he includes it in the list of Lucianic manuseripts at the head of his collations of The Twelve but does not quote it once. The collations in Parsons indicate 96 not only as a Lucianic text, but as the best Lucianic manuscript for Jeremiah.

Codex 229 contains the text of Theodoret's Commentary on Jeremiah. It is very fragmentary and there are many lacunae in it, but as far as can be judged its readings agree in the main with those of $\mathrm{L}$ with which it should be grouped.

62 was elassed as Lucianic by all the earlier scholars except Cornill. Procksch finds it with all three of his groups but mostly with the Lucianic; nevertheless he declines to class it with this group. As a matter of fact the codex is present with the group oftener than not and it occurs more frequently than 144 which Procksch classes as Lucianic. On the other hand it shares a number of sui generis readings ${ }^{19}$ with 144 with which it should be classéd.

Field, Liebmann, Nestle and Procksch all class 144 as Lucianic. Like 62 the codex occurs with $\mathrm{L}$ oftener than not but its numerous absences are worthy of note. In the 64 selections of Lucianic readings given by Procksch 144 occurs only eight times, while

prising, but not a little gratifying, to find that Procksch came to exactly the same conclusions, although his studies had been pursued upon a different line and by a different method.

${ }^{17}$ Praefatio ad Jeremiam.

${ }^{18}$ The Old Latin and the Itala, p. 9. Wrongly quoted by Swete as p. 91.

${ }^{19}$ In Jer. $1-3$ these are $1: 5 ; 2: 9 ; 2: 14 ; 2: 15 ; 3: 1$. 
22.36.48.51.96.231 are almost constant. The variations given by 144 are largely Lucianic but the text is far from a reliable witness to Lucianic readings.

Comparing $\mathrm{L}$ with the Masoretic text on the one hand and with the family of texts represented by $\mathrm{B}$ on the other, these facts are important:

1. In the Masoretic text of Jer. 1-3 there are 33 instances of readings absent from the majority of Greek texts. In 29 instances $\mathrm{L}$ supplies this material; in four instances $\mathrm{L}$ agrees with the other Greek texts.

2. In every one of the 20 instances in which the Greek texts supply material absent from the Masoretic, L agrees with the Greek texts.

3. In 28 instances the Greek texts are either mistranslations or translations based upon a reading different from the Masoretic. In 23 of these L agrees with the Greek texts; in 5 it follows the Masoretic.

4. In 14 instances the Greek texts give a different person or number from that of the Masoretic. In 11 of these $\mathrm{L}$ follows the Greek texts while in three it follows the Masoretic.

5. In 11 instances $\mathrm{L}$ furnishes material found in neither the Greek texts nor the Masoretic, while in two instances $\mathrm{L}$ omits material found in both the Greek texts and the Masoretic.

The editor of the parent text of $\mathrm{L}$ appears to have used as the basis of his work a Greek text somewhat similar to the family represented by $B$ although differing from it in many details. For purposes of correction he seems to have used a Hebrew manuscript, or manuscripts, approximating the present Masoretic text although differing slightly from it. His assumption was that, in process of copying, much material had been omitted from both the Greek and the Hebrew manuscripts, but that none had been added in either. Therefore, in his resultant text he retained all the Greek pluses and restored all the Hebrew pluses. This method naturally gave rise to conflate readings, and such will be found in the text, e. g., 2:2 and 2:25. The changes which he made in the Greek were all stylistic or rhetorical, designed to make more euphonious reading for those for whom he did his work. In Jer. 1-3 the following are to be noted: 
(1) Form of verb $1: 7 ; 2: 16 ; 3: 17$ and the numerous restoration of classical second aorist endings to which attention has already been called.

(2) Spelling $2: 13 ; 3: 5$.

(3) Vocabulary $2: 3 ; 3: 7,13$.

(4) Order of words $1: 18,19 ; 2: 5 ; 3: 9$.

(5) Gender 2:7, 28.

(6) Classical use of genitive $2: 32 ; 3: 12$.

These characteristics can all be explained by the assumption that the editor of the parent text of $\mathrm{L}$ was Lucian of Antioch.

What Lucian did was probably to take the group of manuscripts at his disposal, carefully compare them with other works to which he had access (including that of Origen), and at the same time compare, with the aid of Dorotheus, the Hebrew texts at hand. He then endeavored to give a more or less uniform translation of the Bible as he knew it. This text, together with the more or less accurate copies made from it, became a sort of Authorized Version for the region from Antioch to Constantinople, especially for the men of the Antiochene School and for the early Arians.

The Lucianic recension indicates that the Hebrew text was not yet fixed at the close of the third century, although it had assumed by that time a form closely resembling the present Masoretic. The majority of instances in which Lucian supplied Hebrew pluses to the Greek text are supported also by hexaplaric readings. These additions were therefore in existence by the year 250. In Jeremiah 1-3, however, there are four readings of Lucian supported by the Masoretic text but unnoticed by Origen. These readings are:

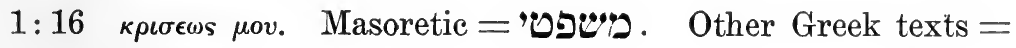

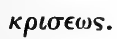

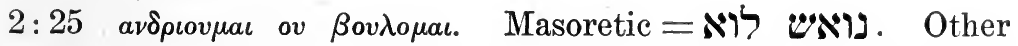

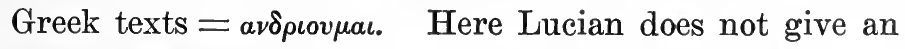
exact restoration but indicates a different reading.

$3: 7 \quad \eta a \delta \epsilon \lambda \phi \eta a v \tau \eta$ s. Masoretic = אחותה. Other Greek texts omit.

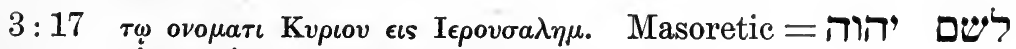
לירושלם Other Greek texts omit. 
It would seem that these additions came into the Hebrew text some time between the years 250 and 300, that is, between Origen and Lucian.

There are, in the same three chapters four Masoretic pluses which were not noticed by Lucian. These are as follows:

1:18 Omitted by Greek texts.

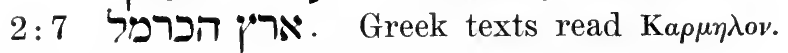

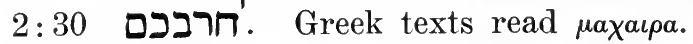

2:34 אביונים נקיים Greek texts read $a \theta \omega \omega \nu$. אבכם

This would indicate that these additions had not come into the Hebrew text by 300 , or at least that their reading was not general.

There are also six instances in which Lucian gives a plus over both the other Greek texts and the Masoretic. These are:

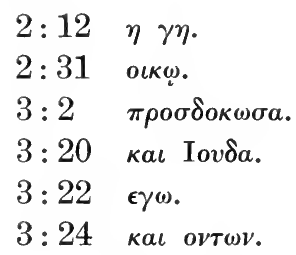

In 2:34 Lucian reads a second person where both the other Greek texts and the Masoretic read a first person.

All these Lucianic pecularities indicate a Hebrew text which was yet in process of formation, but which, in the two or three generations after the time of Origen, had approached more closely its final form as represented in the Masoretic text.

In addition to those manuseripts which have been classified as Lucianic there is another group of texts showing strong relationship with $\mathrm{L}$ but differing from it in many details. 26.88 . 90.91.106.198.228.233.239.Q.A. and the Complutensian Polyglot (abbreviated as Co.) often appear with L, are often regularly absent from L, and appear alone in the following thirteen places in Jer. 1-3:
$1: 2 \quad \mathrm{Q}$. 26.88 . 106.
$1: 4 \quad$ Q.A.Co. 88.90.91.106.
$1: 8$
$\mathrm{Q}$
Co.26.
90.91 .
198.228.233.230.
198.228. 


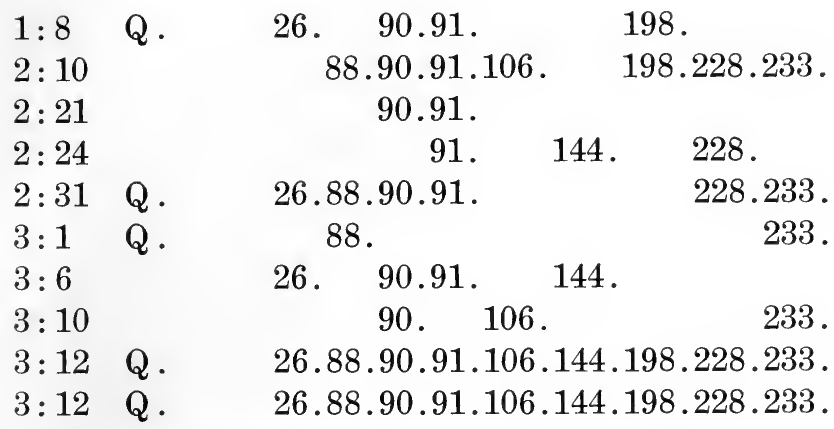

88 has been generally regarded as hexaplaric. Cornill found it akin to the Syro-Hexaplar. It occurs quite often with $\mathrm{L}$ when no other manuscript is found, and upon the assumption of its hexaplaric ancestry its occurrences can be explained.

26 has been generally classed as of Hesychian descent although no direct evidence has yet been found which gives definite aid in identifying the Hesychian recension. The regular appearance of 26 in Jeremiah with Q.90.91.106.233, both with and without $\mathrm{L}$, suggests that it should be grouped with these texts.

Cornill groups 49.68.87.90.91.228.238 as Hesychian in Ezekiel and one cannot fail to note the similarity between this group and Q.26.90.91.106.198.228.233 which are kindred in Jeremiah. Ceriani considered 26.106.198.306 as Hesychian. Procksch classes 26.86.106.198.233.239.306 as prehexaplaric and assigns 91 to the hexaplaric group ${ }^{20}$ while $90^{\circ}$ is assigned to both. Of the hexaplaric group he says, Hier tritt nämlich als vornehmster und greifbarster Charakterzug eine enge Beziehung zum Typus AQ hervor. For purposes of abbreviation I shall call the group Q.26.90.91.106.233 by the initial letters $\mathrm{He}$ because of the possible connection between them and the Hesychian recension.

198 and 228 rightly belong with this group but give in a few places readings that are peculiar to L. ${ }^{21}$ Cornill classed 228 with this group and in general this classification is supported by the readings in Jeremiah. Klostermann, however, noted ${ }^{22}$

\footnotetext{
${ }^{20}$ Procksch has erred here; 90 and 91 should be classed together.

${ }^{21}$ e. g., second aorist endings $2: 8,27 ; 3: 2,7$.

${ }^{22}$ Analecta, p. 13.
} 
that in many instances 228 seemed to follow Lucianic readings and he suggested that the manuscript originally belonged to an Hesychian group but that it had been corercted later from a Lucianic text. From the readings in Jeremiah this is the most satisfactory explanation offered for this text.

The Complutensian Polyglot was classed by Lagarde with the Lucianic texts although the evidence for this is far from convincing. In Jeremiah whenever it agrees with $L$ there are always present one or more members of $\mathrm{He}$ while it often agrees with He when no member of $L$ is present.

The accompanying diagram represents a suggested lineage of certain of the groups of texts with which we have been dealing, and an endeavor to show their relationship to the Masoretic, the Vatican and the Alexandrine texts.

At first there were a number of Hebrew texts the number and exact content of which will never be known. Probably no two of these texts agreed. Some were copied and transmitted in Hebrew; others were translated into Greek. With each recopying and translation there were omissions, additions and alterations. The first Greek texts that represent an endeavor at uniform translation were those of Aquila, Theodotion and Symmachus, all of which, together with some Hebrew manuscripts, were used by Origen who represents the first effort to produce a critical text. At the same time uncritical texts were copied and recopied. The descendants of these can be found in $B$ and $\mathrm{A}$.

To explain the connection between $\mathrm{L}$ and $\mathrm{He}$, as well as the hexaplaric influences in both, I have suggested a parent text, abbreviated as PT, which must have been the basic text with which Lucian worked and upon which he made his corrections, as well as the basic text from which was prepared the recension from which the group $\mathrm{He}$ is descended. This must have been an uncritical text. Traces of influences at work both in B and A are found in it. The anonymous writer in The Church Quarterly Review ${ }^{23}$ pointed out the irregularity with which readings pronounced Lucianic in the Octateuch agree with B or with A or with neither of them. This fact is also noticeable in the prophets and is just as true of $\mathrm{He}$, both with and without $\mathrm{L}$; it can be explained only upon the basis of a common uncritical

${ }^{28}$ Jan., 1901, p. 388. 
Suggested Lineage of Some Groups of Greek Manuscripts.

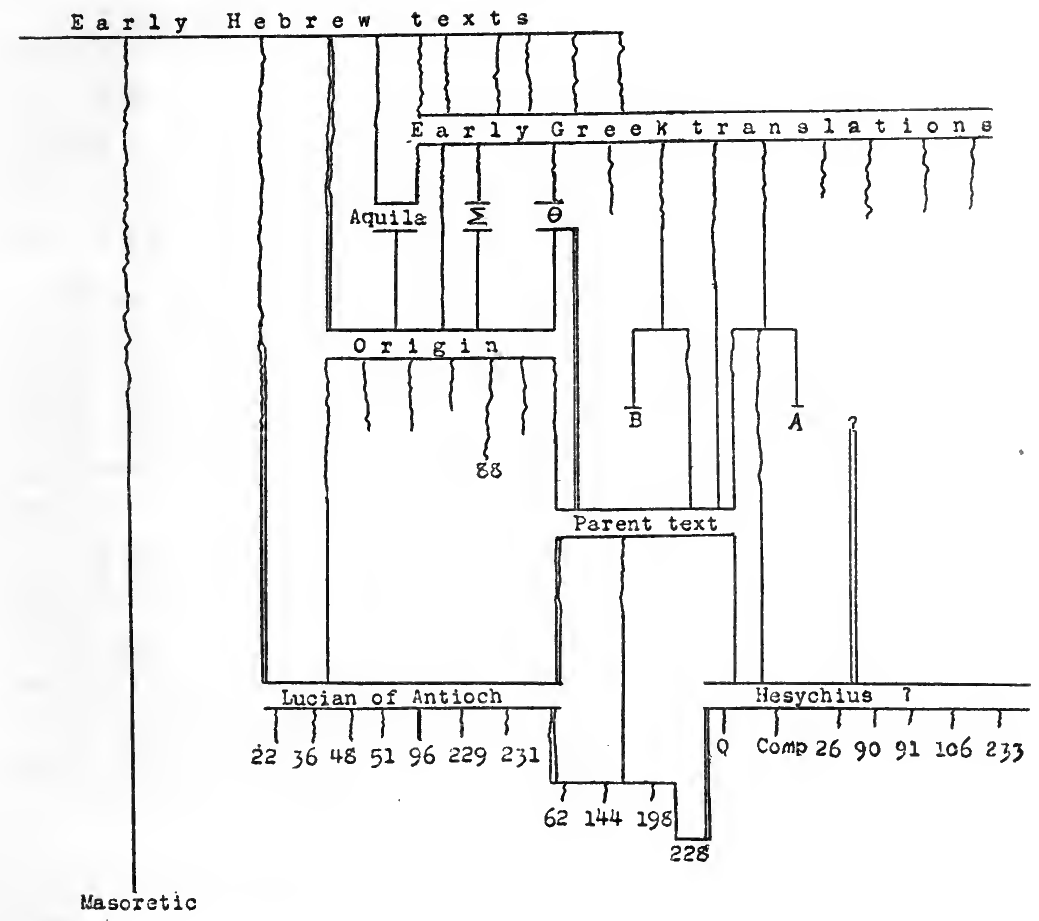



parent text. After the appearance of the Hexapla of Origen, and before the work of Lucian, that is, between the years 250 and 300, copies of this text must have been made. This would be the only explanation of Origenic influence in both $\mathrm{L}$ and $\mathrm{He}$. That this text was not the Hexapla itself is evidenced by the fact that both $\mathrm{L}$ and $\mathrm{He}$ give readings not supported by Origenic: texts. Instances of these readings are as follows:

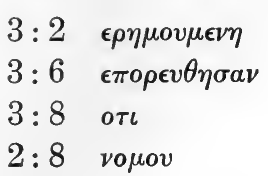

This is an interesting case of a simple dittographic mistake in an early text of the A family, copied in PT and recopied by both $\mathrm{L}$ and $\mathrm{He}$ but corrected by Origen.

PT served as the text of Lucian who, at the same time, had access to the text of Origen, as well as to some Hebrew text or texts. The same text served as the base of He, the author of which made other corrections suggested by some source as yet unknown. These texts have been transmitted in the following groups :

$\mathrm{L}=22.36 .48 .51 .96 .229 .231$.

$\mathrm{L} 2=62.144$. Based upon Lucian, but not as faithful transmis sions.

$\mathrm{He}=26.90 .91 .106 .233$. Kinship not so close, but close enough for grouping.

198 and 228 may have been based upon a text belonging to $\mathrm{He}$, but they were both corrected from a text of the $\mathrm{L}$ family.

The readings and variations in Jeremiah 1-3 may be classed thus :

1. Readings common to L, L2 and He. The source of these is to be found in PT and is often hexaplaric.

2. Readings common to $\mathrm{L}$ and $\mathrm{L} 2$, to be traced to Lucianic influence.

3. Readings peculiar to $\mathrm{L}$, likewise Lucianic.

4. Readings common to $\mathrm{L} 2$ and $\mathrm{He}$, due to $\mathrm{PT}$ readings corrected by $\mathrm{L}$.

5. Readings peculiar to He. The source of these cannot be determined at present, but if Cornill is right in his deductions 
from comparisons with Cyrill of Alexandria, Hesychian influence is strongly indicated.

Whether any of these readings is peculiar or due to hexaplaric influence must be determined in each individual instance by comparison with recognized hexaplaric authorities.

The chief value of the Greek versions of the Old Testament is the aid which they give in determining the quantity of the first Hebrew text, its vocabulary and the form and meaning of its words. For the first of these purposes the value of the Lucianic version is entirely negative. In 1886 Nestle wrote, Die Recension des Lucianus, auf deren Herstellung nach einer mir unbegreiflichen Weise Lagarde zunächst seine Bemühungen gerichtet hat, ist gerade die unbrauchbarste für diejenigen Zwecke für welche wir die $L X X$ am meisten brauchen und gebrauchen. ${ }^{24}$ This statement was repeated by him ten years later and was severely criticized by Wendland. ${ }^{25}$ The study of the text, however, shows that Nestle was correct in his estimate. We find Aquila giving certain pluses over other Greek texts; Origen uses all of these and adds still others; Lucian includes all of the pluses of Origen and adds others; finally, the Masoretic text has more pluses than any of them. The fact that these are in chronological order leads to the supposition that the tendency of copyists was to add to, rather than to omit from previous versions. This means, then, that of all the Greek versions, that of Lucian is the least authentic witness to the quantity of the original Hebrew. We may go farther and say that if the only evidence for a given reading is the version of Lucian there is a strong probability that this reading is a later addition which may be discarded. Of course this principle cannot be adopted as fixed and unvarying; accidents are always to be looked for, and the evidence must be weighed in each individual case.

On the other hand, there are instances, e. g., $2: 11,31 ; 3: 2$, 25, in which Lucian evidently endeavored to render the Hebrew more literally than the texts with which he was familiar. While he took the suggestion in some instances from Origen, in others he apparently acted upon his own initiative. For questions of vocabulary and of the form and meaning of words the Lucianic

${ }^{24}$ Septuaginta Studien, I, p. 9.

${ }^{25}$ Philologus, vol. 57, p. 286. 
version is a more reliable witness. The contention of Nestle, then, is too sweeping, for there are cases where the version of Lucian throws valuable light upon textual study. The service of Lucian, however, is not of enough importance to warrant the labor entailed by an endeavor to complete the work of Lagarde. A more useful work would be a catalogue of Lucianic readings, prepared upon more strict principles than the work of Lagarde, and accompanied by notes which would indicate the source of the readings. 


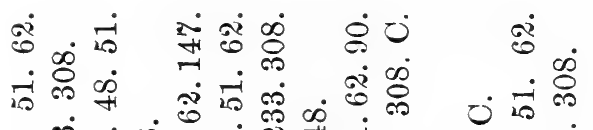

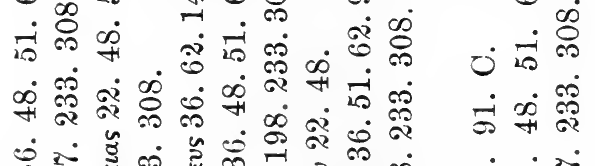

$$
\begin{aligned}
& \text { क्ष } \\
& \text {.尹̃ }
\end{aligned}
$$

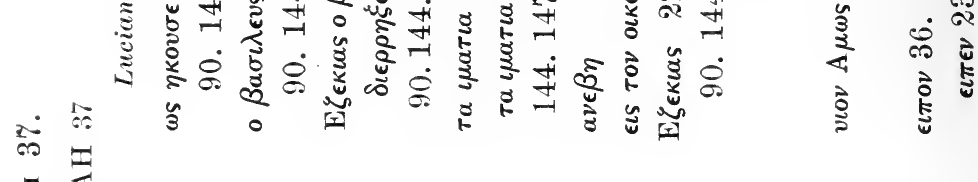

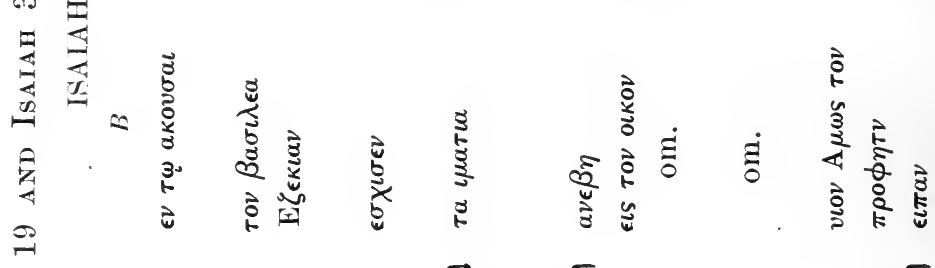

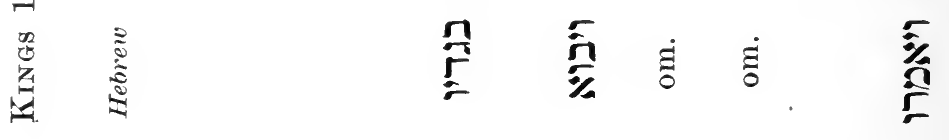

$$
\begin{aligned}
& \text { स } \\
& \text { 5. } \\
& \text { 量 }
\end{aligned}
$$

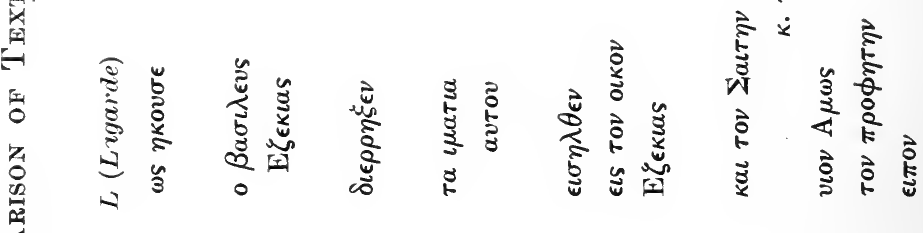

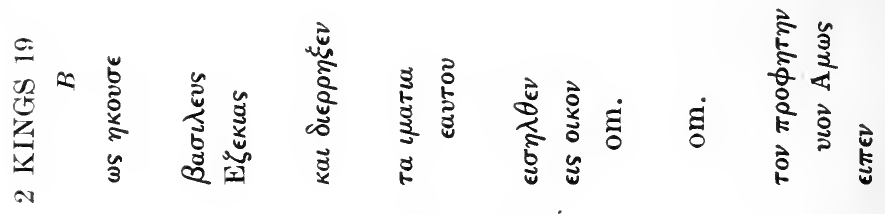

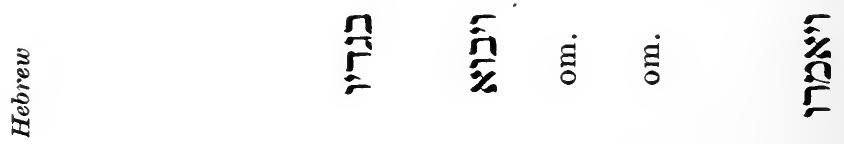


YERKES: LUCIANIC VERSION OF THE OLD TESTAMENT 187

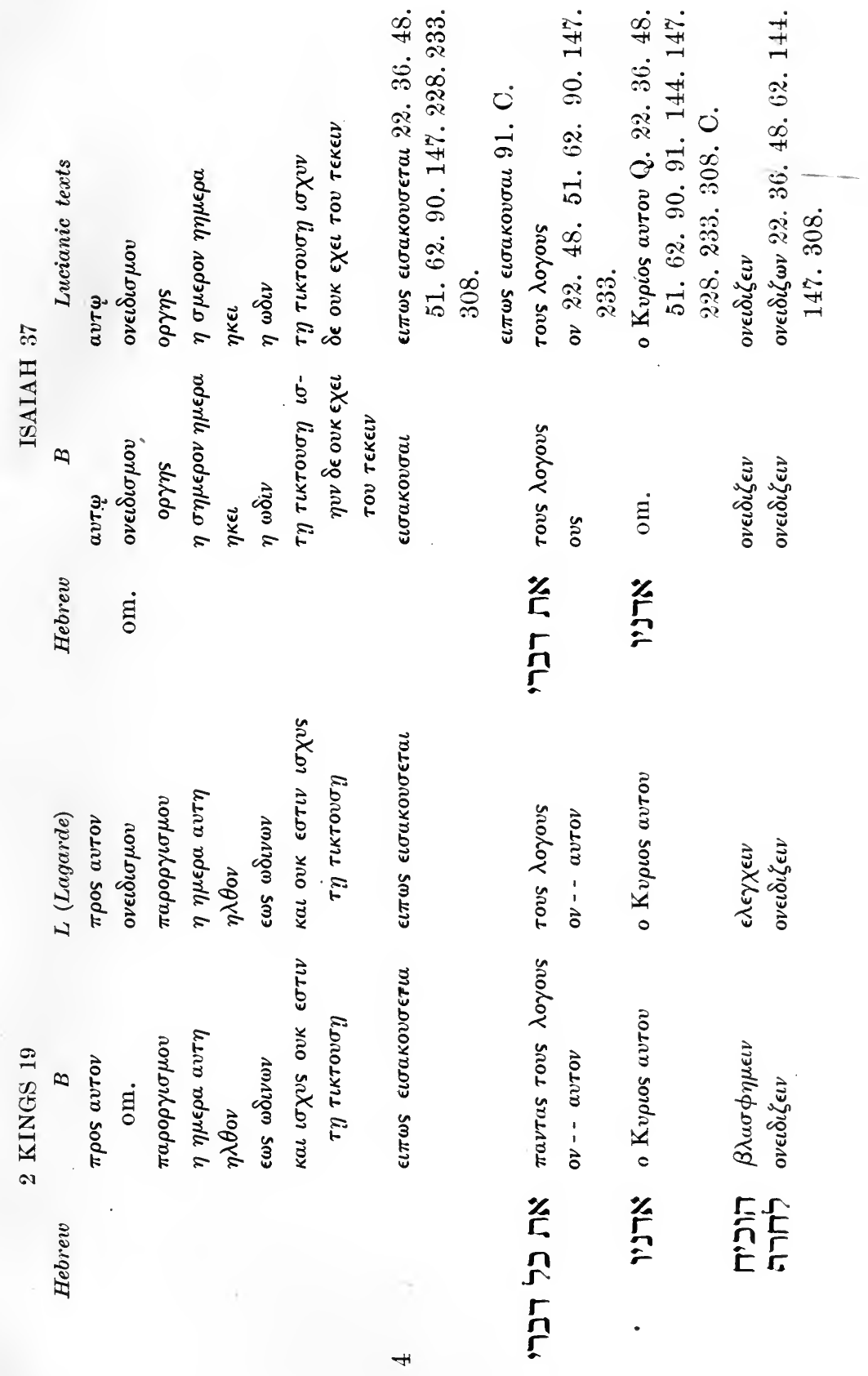




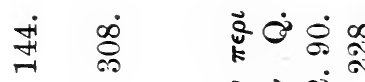

$$
\begin{aligned}
& \text { க. } \\
& \text { है }
\end{aligned}
$$

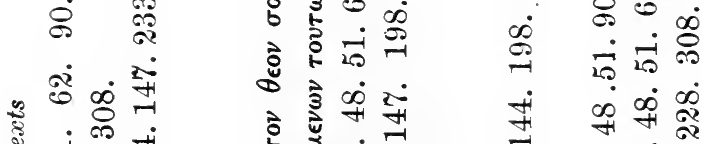

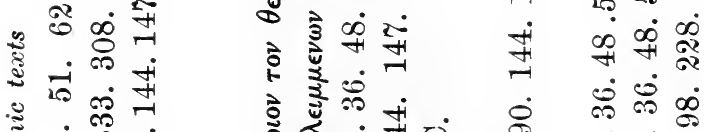

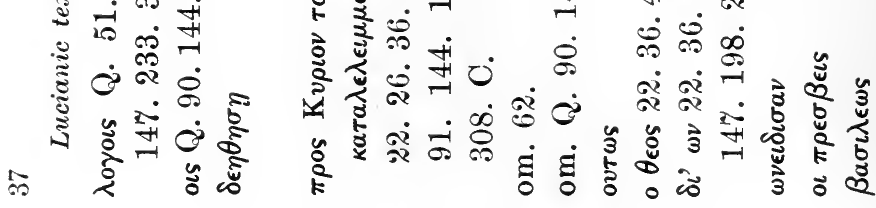

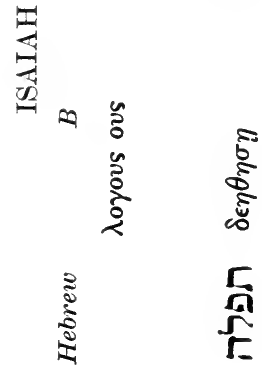

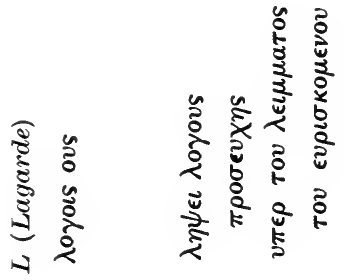

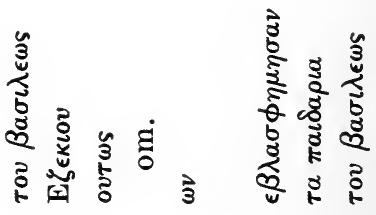

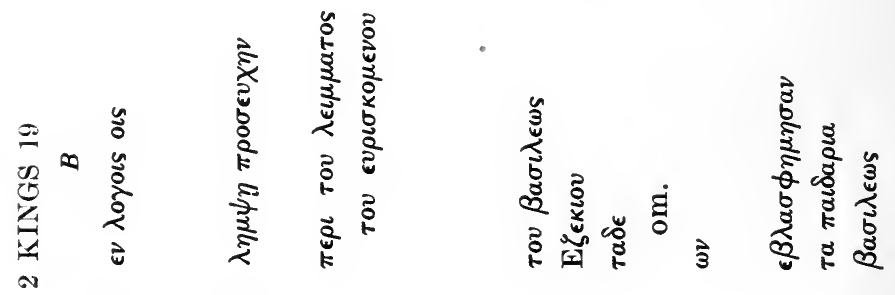

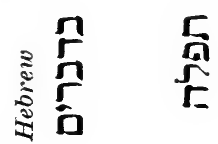

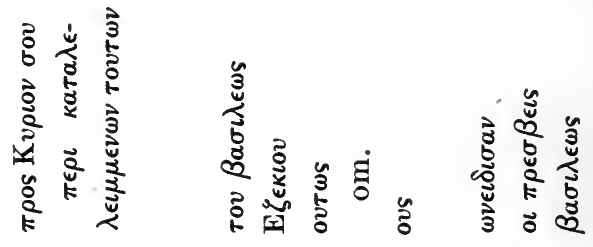


YERKES: LUCIANIC VERSION OF THE OLD TESTAMENT 189

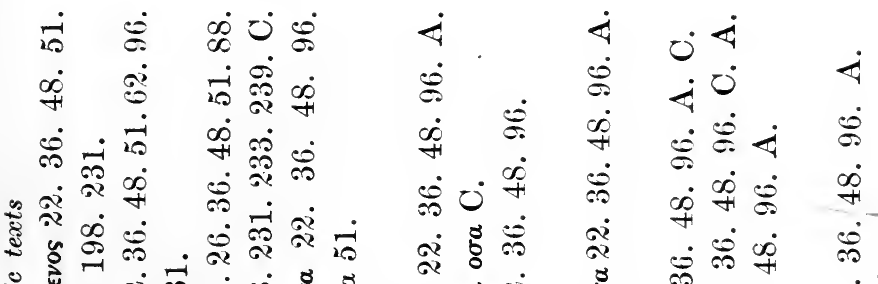

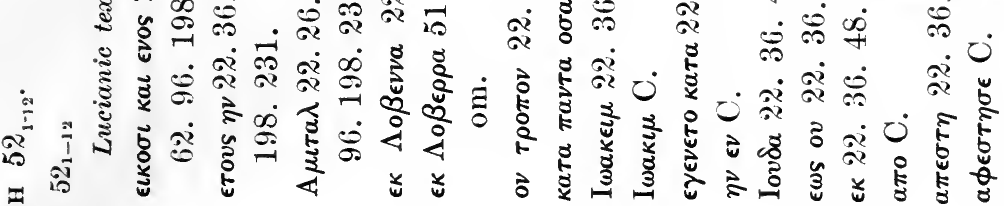

至

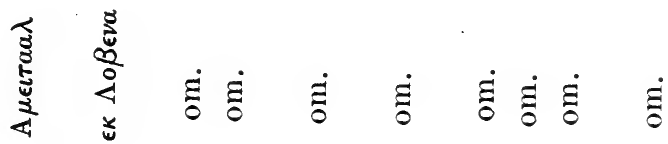

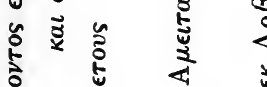

हू

点

QP

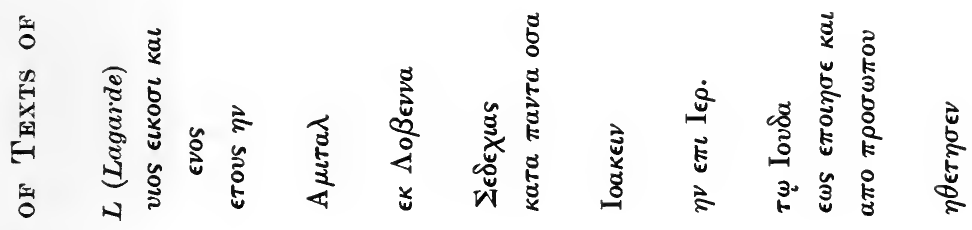

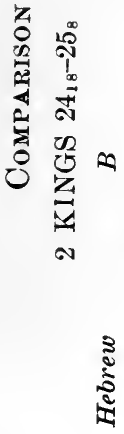




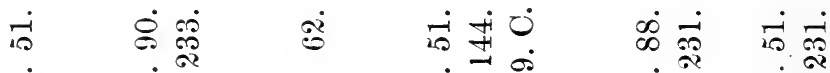

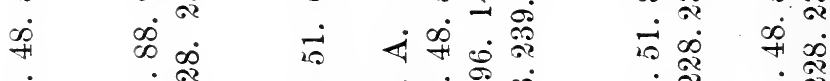

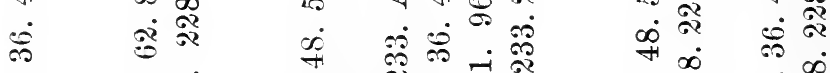

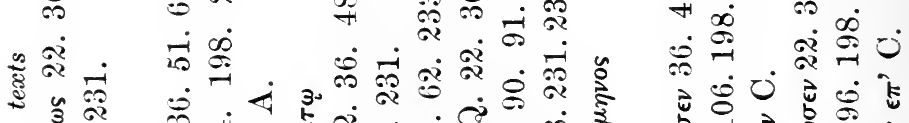

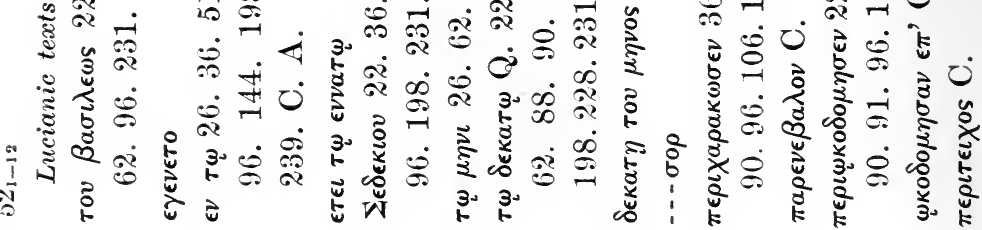

空心

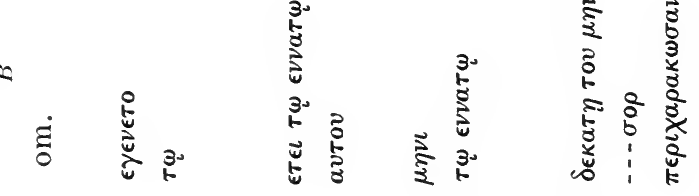

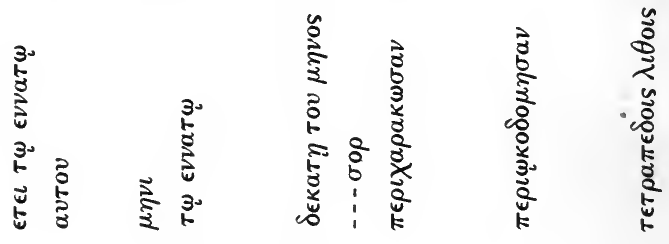

次

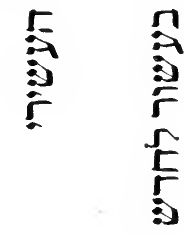

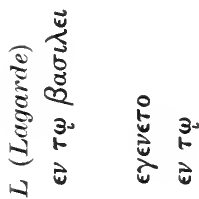

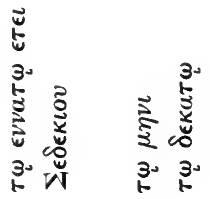

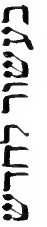

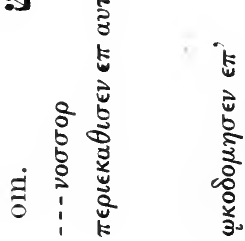

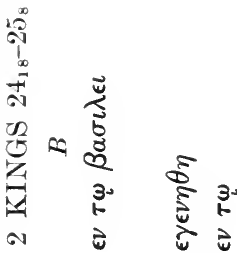

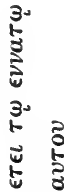

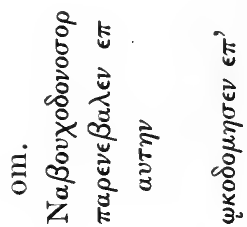

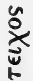

$\frac{\sqrt{2}}{3}$

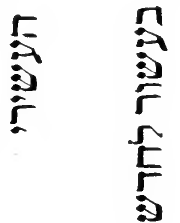




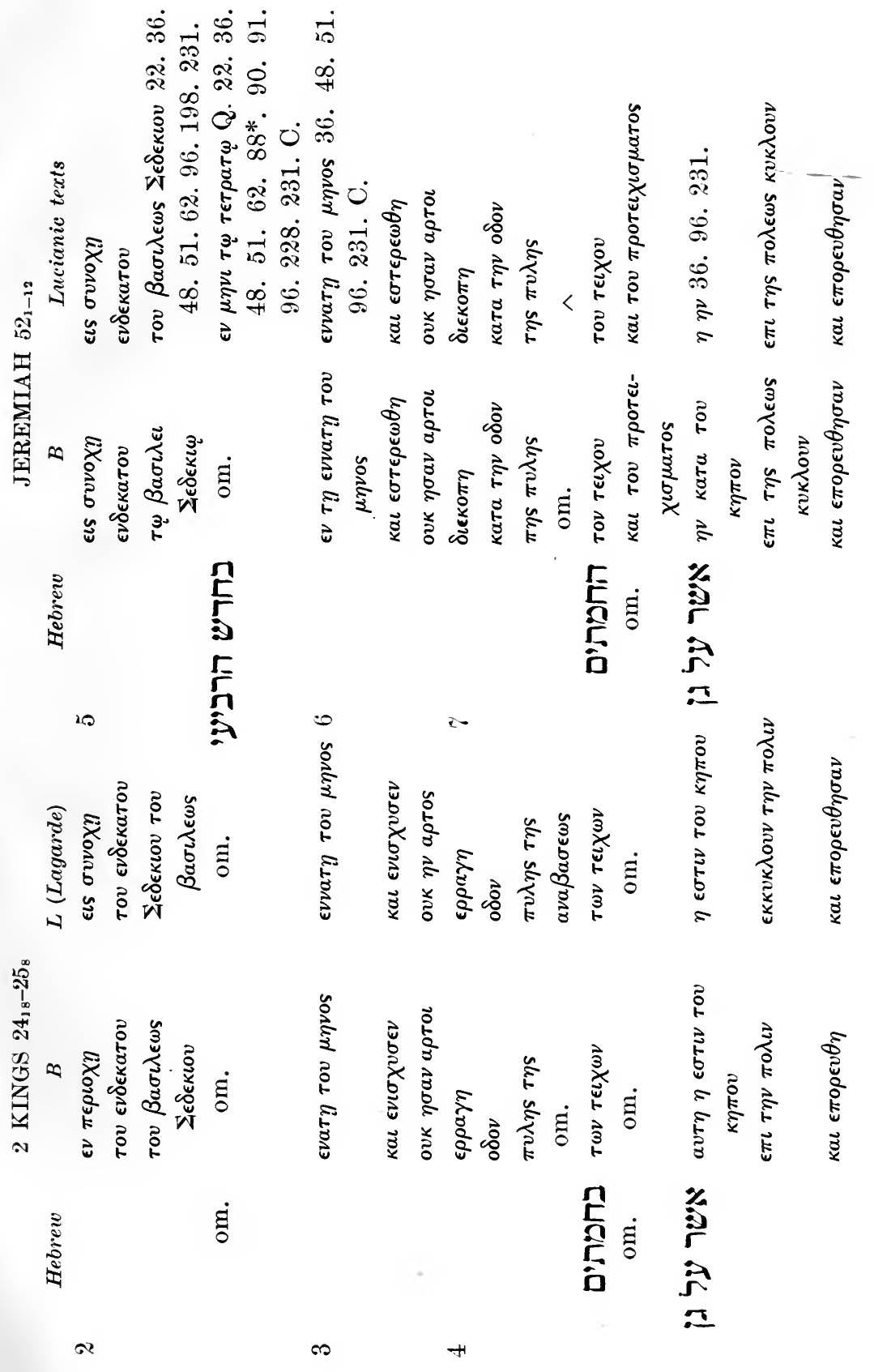




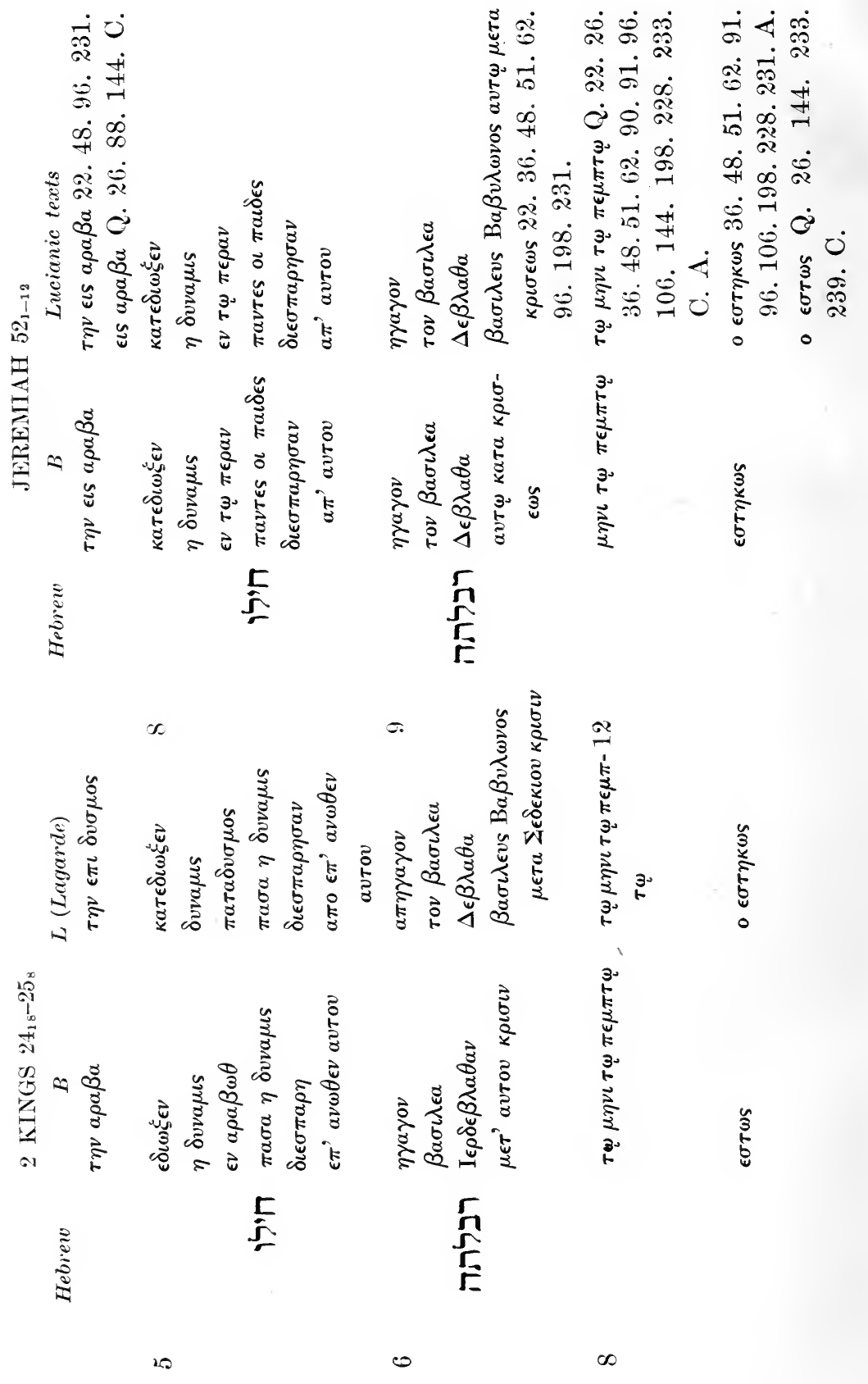





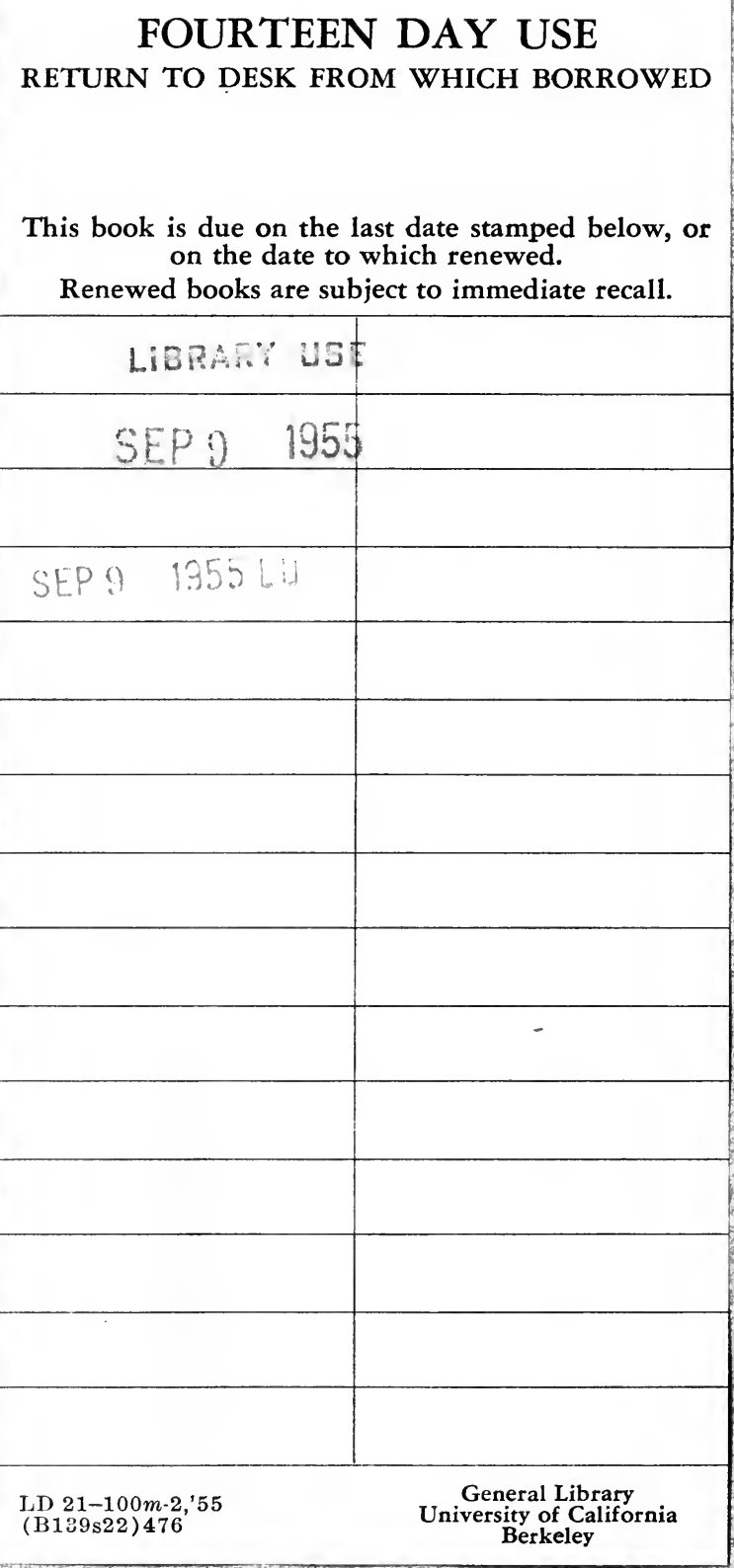


YC 27586

$$
\begin{aligned}
& 42898 \\
& B 564 \\
& 281 / 4
\end{aligned}
$$

UNIVERSITY OF CALIFORNIA LIBRARY 
